\author{
Э. Л. РУБИН \\ ${ }^{1}$ Школа права, Университет Вандербильта, г. Нэивилл, шт. Теннесси, США
}

\title{
ГОСПОАСТВО НОРМ*
}

Цель: оспаривание теории рационального выбора с позиции права, истории и культуры.

Методы: диалектический подход к познанию социальных явлений, позволяющий проанализировать их в историческом развитии и функционировании в контексте совокупности объективных и субъективных факторов, который определил выбор следующих методов исследования: системно-структурного, формально-юридического, сравнительного.

Результаты: в первой части работы рассматривается, какими мотивациями руководствовались люди из других сообществ в ситуациях, в которых в нашем обществе доминировало бы стремление к личной выгоде. Рассуждения построены на трех примерах: один из истории Древнего Рима, один из европейской истории Средних веков и один из современной неевропейской культуры. Во второй части работы проанализированы причины, по которым максимизация материальной выгоды стала доминирующей мотивацией в современном западном обществе. В работах по исторической социологии доказывается, что причина этого лежит в кальвинизме. Однако данная гипотеза имеет ряд недостатков. В статье приведены аргументы в пользу того, что современная склонность к сопереживанию возникла в результате долговременного развития, в частности, секуляризации, урбанизации и коммерциализации. В заключительной части работы исследована связь между господствующей на Западе нормой - максимизацией материальной выгоды - и частными нормами, выдвигаемыми микроэкономической теорией. Представляется, что некоторые из этих норм являются внутренними по отношению к господствующей норме, а значит, их можно выразить в терминах материальной выгоды, тогда как другие отражают дополнительные нормы, существующие в обществе в целом и иногда противоречащие господствующей норме. Исторический взгляд на максимизацию материальной выгоды как на господствующую, но не универсальную для всего человечества норму позволяет признать существование других норм, не пытаясь втиснуть их в прокрустово ложе единственной модели мотивации человека. Научная новизна: в статье обоснован вывод о том, что максимизация личной материальной выгоды является господствующей нормой в нашем обществе, которая определяет значительную часть поведения, но поскольку это лишь норма, а не универсальная модель поведения человека, то она может быть изменена или поглощена другими нормами, если условия будут способствовать этому. Поведение, не укладывающееся в рамки рационального выбора, не следует считать уходом в область иррациональности. Напротив, оно представляет собой естественное взаимодействие разнообразных мотивов, существующее в любом сложном обществе, а источниками такого поведения будут все события повседневности. Каждый отдельный мотив требует отдельного объяснения, но не требует толкования тот факт, что они взаимодействуют друг с другом.

Практическая значимость: основные положения и выводы статьи могут быть использованы в научной и педагогической деятельности при рассмотрении вопросов, связанных с правовым поведением человека.

Ключевые слова: право; экономика; рациональный выбор; микроэкономическая теория; господствующая норма; общественная норма; превалирующая норма

Благодарность. Выражаю благодарность моему научному ассистенту Ларе Ассаф за помощь в подготовке данной paботы.

Как цитировать русскоязычную версию статьи: Рубин Э. Л. Господство норм // Актуальные проблемы экономики и права. 2017. Т. 11, № 2. С. 199-219. DOI: http://dx.doi.org/10.21202/1993-047X.11.2017.2.199-219

\footnotetext{
* Впервые статья опубликована на английском языке издательством Routledge. По вопросам коммерческого использования просьба обращаться за разрешением в издательство Routledge.

Цитирование оригинала статьи на английском языке: Rubin E. The dominance of norm // Law and Economics: Philosophical Issues and Fundamental Questions /ed. Hatzis A. N., Mercuro N. Routledge, 2015. Pp. 43-68.
} 


\author{
E. L. RUBIN ${ }^{1}$ \\ ${ }^{1}$ Vanderbilt University Law School, Nashville, TN, USA
}

\title{
THE DOMINANCE OF NORM*
}

Objective: to revisit the debate about rational choice theory from the legal, cultural and historical perspectives.

Methods: dialectic approach to the cognition of social phenomena, allowing to analyze them in their historical development and functioning in the context of the integrity of subjective and objective factors; this determines the choice of the research methods: systemic-structural, formal-legal, and comparative.

Results: The first part of this chapter will explain the way in which people in societies different from our own were subject to other motivations in situations where self-interest would tend to dominate in our society. The reasoning is based on three examples, one drawn from the history of Ancient Rome, one from the High Middle Ages of the European society, and one from a contemporary non-Western culture. The second part of the chapter analyzes the reason why material self-interest maximizing became a dominant motivation in the modern Western society. The works on historical sociology attribute this development to Calvinism, but this hypothesis suffers from some serious defects. In the article we prove that the modern sensibility resulted from much longer-acting trends, specifically secularization, urbanization and commercialization. The final section of the chapter explores the relationship between the West's prevailing norm of self-interest maximization and the particular norms that have been discussed in microeconomic theory. It argues that some of these norms are internal to the prevailing one, and are thus explicable in terms of material self-interest, but that others reflect additional norms in the general society that exist alongside, and sometimes in competition with, the prevailing norm of self-interest maximization. The historically-based view that self-interest maximizing is a prevailing norm, rather than a human universal, allows these other norms to be acknowledged in a plausible and realistic manner, rather than being explained away by a Procrustean, and ultimately unconvincing effort to fit them into a unitary model of human motivation.

Scientific novelty: the article proves that material self-interest maximizing is a prevailing norm in our society, determining a good deal of observed behavior. However, because it is a norm, and not a human universal, it can be readily altered or alloyed by other norms when circumstances render those considerations operative. Thus, behavior that cannot be explained as rational choice should not be regarded as enigmatic lapses into irrationality. Rather, it represents the natural interplay of varying attitudes that any complex society displays, the range of behavior resources that individuals within such a society will naturally draw upon in daily life. Each particular motive may require explanation, but the fact that they are mixed together does not.

Practical significance: the main provisions and conclusions of the article can be used in scientific and pedagogical activity when considering the issues of the legal behavior of the humans.

Keywords: Law; Economics; Rational choice; Microeconomics theory; Prevailing norm; Public norm

Acknowledgements. I want to thank my research assistant, Lara Assaf, for her assistance with this article.

For citation of Russion version: Rubin E. L. The dominance of norm, Actual Problems of Economics and Law, 2017, vol. 11, No. 2, pp. 199-219. DOI: http://dx.doi.org/10.21202/1993-047X.11.2017.2.199-219

\section{Введение}

Учет общественных норм представляет собой наиболее сложную и результативную реакцию микроэкономической теории на вызовы теории рационального выбора [1-4]. В ответ на идею о том, что люди действуют под влиянием более широкого и сложного ряда мотиваций, - а эта идея в течение целого столетия получала поддержку эмпирических и эпистемологических исследований [5-7] - сторонники микроэкономической теории попытались инкорпорировать общественные нормы в свою модель поведения, а в тех случаях, когда такое инкорпорирование было

\footnotetext{
* The article is first published in the English language by Routledge Publishing House. For commercial use, please contact Routledge licensing office.

For original publication: Rubin E. The dominance of norm // Law and Economics: Philosophical Issues and Fundamental Questions / ed. Hatzis A. N., Mercuro N. Routledge, 2015. Pp. 43-68.
} 
невозможным - изменить модель. Однако по вполне понятным причинам они категорически не желали отказаться от этой модели, дававшей такие впечатляющие результаты, а также не желали и отказаться от своего убеждения, что другие общественные науки неспособны внести свой вклад в эту область знания из-за отсутствия у них математической методологии, присущей микроэкономической науке. Для каждого, кто проявит хотя бы малую толику беспристрастности, аргументы против теории рационального выбора очевидны, однако трудно поверить, что все огромное здание современной микроэкономики построено на песке.

В данной работе мы вновь оспариваем теорию рационального выбора и пытаемся разрешить эту дилемму с культурной и исторической точек зрения. Мы считаем, что в целом подход общественных наук к проблеме мотивации человека верен, так как люди действуют под влиянием широкого круга самых разнообразных мотиваций. Однако в нашем обществе самой мощной мотивацией является та, которую выделяет микроэкономика, а именно желание человека максимизировать свою личную материальную выгоду. Поэтому микроэкономическая теория рационального выбора обладает для нас большой объяснительной силой, но это происходит не потому, что она универсальна. Напротив, она представляет собой лишь одну из норм, занимая то же место, которое занимали, например, стремление к чести, спасению или другим ценностям в более ранних обществах [8].

Разумеется, теория рационального выбора применима и к более ранним историческим периодам. Во-первых, общественные нормы более ранних обществ допускали применение рационального выбора в ограниченных областях. Кроме того, человеческая психология производит широкий спектр индивидуальных вариаций. В самых жертвенных сообществах были оппортунисты и материалисты, так же как и в нашем обществе есть истинные альтруисты. Из тех немногих правил человеческого поведения, которые могут считаться по-настоящему универсальными, одно гласит, что поведение всегда в очень большой степени определяется господствующими нормами, а второе - что всегда найдутся люди, нарушающие эти господствующие нормы.

Отсюда следует важнейшее эпистемологическое соображение, которое составляет вторую основную тему нашего исследования. Изучая обширную историю человечества, мы всегда можем найти примеры поведения, соответствующего модели рационального выбора. Однако существует огромная опасность переоценить значение этих примеров, а значит, и неверно понять общество тех эпох, потому что максимизация личной материальной выгоды является в нашем обществе очень сильной нормой. Другими словами, когда мы рассматриваем другие сообщества, мы склонны интерпретировать их согласно нашей нормативной системе взглядов; мы видим их сквозь призму личной материальной выгоды. Мы склонны преувеличивать значимость тех личностей, чьи взгляды наиболее сходны с нашими, потому что мы понимаем таких людей; в поведении же тех, кто не похож на нас, мы ищем более глубокую мотивацию, приближенную к нашей; если же они сами объясняют свое поведение не материальными мотивами, то мы склонны обвинять их в сознательной или подсознательной неискренности.

Эти нарушения восприятия еще более усугубляются тем, что мы ощущаем себя как вершину развития человечества, наше общество - как значительно более совершенное по сравнению с предшествующими; мы считаем, что можем смотреть на предков с высоты своих знаний и рационального мышления. Это всего лишь доказывает, что мы находимся во власти все тех же иллюзий. Возможно, мы единственное общество, обладающее мотоциклами и персональными компьютерами, но мы испытываем те же концептуальные ограничения, что и раньше, и являемся жертвами тех же ограниченных рамок восприятия, включая восприятие нашего культурного превосходства. Таким образом, мы не можем полностью доверять нашей способности судить о сходстве или различии норм другого общества с нашими нормами. Это не означает, что мы не можем исследовать относительную ценность своих и чужих норм, но нужно подходить к данному вопросу с полным осознанием самих себя и со смирением.

В первой части данной работы мы рассмотрим, какими мотивациями руководствовались люди из других сообществ в ситуациях, в которых в нашем обществе доминировало бы стремление к личной выгоде. Мы увидим, каким образом мы склонны интерпретировать их поведение в терминах максимизации личной материальной выгоды и почему такой подход неверен. Наши рассуждения будут построены на трех 
примерах: один из истории Древнего Рима, один из европейской истории Средних веков и один из современной неевропейской культуры. В качестве примеров мы рассматриваем бегство куриалов, реконструкцию Шартрского собора и бедствия народности ик из северной части Уганды. Во второй части главы мы обсуждаем причины, по которым максимизация материальной выгоды стала доминирующей мотивацией в современном западном обществе. В двух известнейших работах по исторической социологии доказывается, что причина этого лежит в кальвинизме: это работы M. Weber «Протестантская этика и дух капитализма», впервые опубликованная в 1904-1905 гг. [9], R. Tawney «Религия и становление капитализма», вышедшая в 1926 г. [10]. Несмотря на такую сильную поддержку, гипотеза имеет ряд серьезных недостатков, и в данной статье мы приводим аргументы в пользу того, что современная склонность к сопереживанию возникла в результате долговременного развития, в частности, секуляризации, урбанизации и коммерциализации. В последней части работы мы исследуем связь между господствующей на Западе нормой - максимизацией материальной выгоды - и частными нормами, выдвигаемыми микроэкономической теорией. Мы считаем, что некоторые из этих норм являются внутренними по отношению к господствующей норме, а значит, их можно выразить в терминах материальной выгоды, тогда как другие отражают дополнительные нормы, существующие в обществе в целом и иногда противоречащие господствующей норме. Исторический взгляд на максимизацию материальной выгоды как на господствующую, но не универсальную для всего человечества норму позволяет признать существование других норм, не пытаясь втиснуть их в прокрустово ложе единственной модели мотивации человека.

\section{НОРМЫ, ПРЕВАЛИРУЮЩИЕ В РАЗЛИЧ- НЫХ СООБЩЕСТВАХ}

При рассмотрении нашей современной, экономико-ориентированной системы мотиваций в ее культурном и историческом контексте важно уточнить содержание этого понятия. При этом обычно опираются на концепцию J. Ferejohn о различиях между слабой и сильной рациональностью [11]. Слабая рациональность означает, что в поведении людей проявляются определенные формальные или структурные качества: стремление максимизировать полезность для действующего лица (т. е. собственные цели актора), последовательность и транзитивность (т. е. если актор отдает предпочтение А перед В и В перед $\mathrm{C}$, то он отдает предпочтение А перед C), ориентированность на личность (т. е. эгоистичность превалирует над альтруистичностью или направленностью на другого). Сильная рациональность означает, что в поведении проявляются также сущностные качества, главное из которых состоит в том, что актор старается максимизировать материальную выгоду или достижение собственных интересов.

Хотя концепция рациональности полезна при анализе или изучении процесса принятия решений внутри отдельного общества, она не дает достаточных оснований для выводов, о которых заявляют специалисты по микроэкономике. Их заявления неизбежно опираются на свойство сильной рациональности - стремление людей максимизировать свою материальную выгоду. Необходимость более широкого, сущностного подтверждения этого тезиса становится очевидной при проведении кросскультурного анализа, что и будет сделано в данной главе. Слабая рациональность определяет полезность, направленную на достижение любой цели, включая наиболее символические, как честь, а на достижение сверхъестественных целей - как спасение. В следующей работе мы покажем, что в ранние периоды западноевропейской истории именно такие цели люди определяли как основу своих поступков [8]. Если мы включаем рассмотрение таких целей в наш анализ, то при определении мотивов выбора становится совершенно невозможно опираться на выявленные предпочтения, так как в этом случае любое поведение можно объяснить как рациональное стремление достичь символических или сверхъестественных целей. При этом внешний наблюдатель может оценивать только те усилия, которые приводят к видимым результатам, например, материальной выгоде.

Включение символических или сверхъестественных целей не только делает проблему достижения цели не поддающейся измерению, но и, что еще хуже, подрывает формальные признаки слабой рациональности, тем самым лишая всю концепцию возможности называться теорией рациональной деятельности в каком бы то ни было смысле. Вполне очевидно, что при этом исчезает свойство индивидуалистской направленности. Конечно, можно сказать, что от- 
дельный актор стремится защитить свою честь или достичь для себя спасения в качестве индивидуальной выгоды, но обе эти системы ценностей могут потребовать и чисто альтруистического поведения. Во-вторых, эти цели подрывают свойство максимизации, поскольку они позволяют индивидууму достичь цели в момент своей смерти, прожив всю жизнь согласно другой модели поведения [12, рр. 302-307, Книга Судей, гл. 16: 28-31]1․ И наконец, эти цели ставят под сомнение даже свойство транзитивности, поскольку они чрезвычайно абстрактны. Актор, отдающий предпочтение чести перед деньгами (он желает быть филантропом) и деньгам перед сексом (он женится на нелюбимой женщине ради денег), может при этом отдавать предпочтение сексу перед честью (он завсегдатай домов терпимости). Это становится возможным потому, что такие абстрактные цели, в отличие от богатства, легко модифицируются в зависимости от обстоятельств и желания. Утверждение, что люди стараются скорее максимизировать свою пользу, чем получить материальные преимущества, означает всего лишь, что они стараются получить то, что хотят. На самом деле даже это утверждение не может быть признано универсальным; как доказал Harry Frankfort [13] и художественно выразил Достоевский [14], внутри человека могут содержаться различные и противоречивые уровни желаний. Однако в целом доминирующим будет желание получить то, что хочется, но эта мотивация является слишком широко распространенной, слишком неопределенной и, что самое главное, слишком плохо поддающейся наблюдению, чтобы служить основой для конкретной теории поведения человека.

Микроэкономическая теория утверждает, что люди стремятся максимизировать свои материальные интересы. В целом это легко определить в рамках денежной экономики, поскольку при этом не приходится разбираться в причинах, почему у людей

1 Манфред, король Сицилии, 1258-1266, всю свою жизнь был вольнодумцем и врагом церкви, но, по словам Данте, покаялся, умирая на поле битвы, тем самым получив место в Чистилище, что, разумеется, является спасением («Мои ужасны были прегрешенья; Но милость божья рада всех обнять, Кто обратится к ней, ища спасенья». - Перевод М. Лозинского) (Данте 2003: 306). Книга Судей, глава 16, описывает смерть Самсона, которого его братья похоронили в могиле отца, признав, что он ни восстановил свою честь, ни заслужил спасения. возникли те или иные предпочтения, другими словами, каковы же материальные интересы конкретного человека [15]. В Древнем Египте, где монетарная система отсутствовала, было бы труднее определить, имеется ли у конкретного сапожника рациональное основание для продажи своих сапог, потому что мы не знали бы о его субъективной оценке ценности тех товаров, которые он получил бы взамен. Поскольку при определенных условиях люди могут неправильно представлять свои предпочтения [16], оценка выгоды при обмене дает хороший пример максимизации своих интересов. Если сапожник продает свой товар за максимальную стоимость, которую может получить, то мы делаем вывод, что он действует рационально, и при этом мы не интересуемся тем, на что он предпочтет потратить деньги [17, pp. 775-784].

Всегда ли было так? Этот вопрос можно поставить абстрактно, и при этом он будет охватывать весь спектр человеческого поведения. Можно задать этот вопрос и в аспекте систематизации истории, и тогда он будет затрагивать весь спектр опыта человечества. В данный момент мы рассмотрим этот вопрос на примерах. Разумеется, такой подход не лишен множества хорошо известных недостатков, однако наша цель - не столько дать определение, сколько показать, что люди в различных обществах имеют мотивации, отличные от наших, а также исследовать нашу тенденцию интерпретировать поведение других в соответствии с нашими собственными привычными мотивациями.

\section{Три примера}

Бегство куриалов в Древнем Риме

В городах Древней Греции общественные работы и праздники часто финансировались с помощью «служения» (liturgies) - выплат богатых граждан на определенные цели ${ }^{2}$. Эту практику часто сравнивают с современным спонсорством. Примеры типичных

2 Термин liturgy («служение») по-гречески означает «публичная служба». Термин связан с церемонией богослужения, проводимой католическим священником (или, конкретнее, с церемонией причастия в православии), поскольку эта церемония была публичной, в отличие от обрядов, проводившихся в эпоху раннего христианства в частных домах. В современном английском языке слово service («служба») используется в обоих значениях - «общественная функция» и «религиозная церемония». Практику служения (liturgy) иногда называют evergetism («благотворительность») [18, pp. 107-110]. 
служений: содержание военного корабля в течение года, финансирование театральной постановки, организация пиршества для трибы (триба - округ в Древнем Риме) [19, pp. 228-229; 20, pp. 195-234]. Когда римляне завоевали Грецию, они не делали никаких попыток изменить внутреннюю систему управления в греческих городах, а просто присоединили их к империи. Основным изменением ситуации было лишь установление мира и лишение независимости во внешней политике. Побежденные города облагались налогом, но налоги взимались с города в целом, как дань, а не напрямую с жителей города [21, pp. 107-111; 22, pp. 262-266; 23, pp. 143-151]. Очень часто деньги на эти выплаты поступали от состоятельных горожан, что также было одной из форм служения.

Когда римляне завоевали неурбанизированные кельтские территории на западе - Галлию, Испанию, Нидерланды и Британию, - они решили организовать свое правление на местах по образцу греческих городов-государств ${ }^{3}$. Легионеры заложили новые города по единому плану, с двумя длинными прямыми перпендикулярными улицами, с форумом на их пересечении и крепостью на окраине [23, pp. 246-251; 24 , pp. 37-40, 123-151; 25, pp. 101-113]. Вместо конституций греческих городов, которые не очень хорошо выполняли свою функцию ${ }^{4}$, римляне внедрили столь же единообразную, как планировка городов, политическую структуру. «У них была одна основная конституция, составленная в Риме, которую приняли все города, изменяя лишь некоторые детали в зависимости от своих условий» [24, p. 39]. На место древних аристократических элит, составлявших правящий класс в греческих городах, римляне назначили состоятельных горожан, которые стали управляющим органом, курией. Эти люди (куриаль -curiales) должны были, кроме того, поддерживать город своими служениями, спонсировать праздники, общественные работы

\footnotetext{
3 Некоторые из этих областей, например, Сицилия, современный Прованс и часть средиземноморского побережья Испании были к тому времени уже эллинизированы, так что римская административная структура могла быть наложена на существовавшую структуру города-государства, как это происходило на востоке [23, pp. 146-148].

4 Аристотель и его ученики, видимо, задокументировали конституции около 170 городов-государств. До наших дней дошла лишь одна - конституция Афин, предположительно написанная самим Аристотелем [26, р. 553].
}

и выплачивать подати, которые империя наложила на каждый из новоиспеченных городов [18, pp. 106-115; 23 , pp. 143,$146 ; 27$, pp. 50-57].

Бегство куриалов началось почти сразу же после того, как была установлена эта система. В доримской Греции города были самостоятельными политическими единицами, ареной политической активности, общественной жизни и становления личной репутации. Несомненно, территория города включала в себя окружающие сельскохозяйственные земли, но все, что находилось за их пределами, принадлежало либо другому городу, либо неэллинистическому племени; если территория даже не была занята никем, она была определенно небезопасной для пребывания. Однако, как только был создан рах Romana $^{5}$, эта ситуация резко изменилась. Земля за городом стала просто другим регионом той же провинции единой империи, а значит, настолько же безопасной, как и город. Политическая власть зависела от Рима, а не от притязаний самого города; общественная и культурная жизнь все больше принимала имперский характер по своему масштабу и качествам [23, pp. 223-254; 24, pp. 117-118; 28, pp. 24-41; 29, pp. 27-36]. В этих условиях обязанность выплачивать подать за город или нести другие расходы стала восприниматься как бремя, а не почетная обязанность. В результате богатые люди стали покидать города, предпочитая тратить ресурсы на собственные виллы, а не на города, где они раньше служили [23, pp. $178-182 ; 24$, pp. 35-36; 25, pp. 121-130; 30, pp. 588-614]. Этот процесс бегства куриалов подорвал всю систему местного управления в Европе. Ко II в. римские власти попытались подкрепить систему с помощью юридических механизмов, таких как запрет покидать город; к IV в. они практически прекратили эти попытки и перешли к прямому налогообложению граждан и бюрократическому управлению в городах [31, pp. 26-28; 32, pp. 168-171].

\section{Восстановление собора в Шартре}

В ночь с 10 на 11 июня 1194 г. страшный пожар разрушил город Шартр, в том числе его знаменитый

5 Pax Romana (Пакс Рома́на, лат. «Римский мир»), или «Августов мир», - длительный период мира и относительной стабильности в пределах Римской империи эпохи Принципата. 
собор. Уцелел лишь западный фасад собора ${ }^{6}$. Считалось, что этот собор, посвященный Деве Марии, был заложен за сто лет до ее рождения, во исполнение пророчества. В нем хранилась одна из самых драгоценных реликвий христианского мира - Священная Туника, в которой Дева Мария рожала Христа [34, p. 160]. К моменту пожара поклонение Марии, которое в эпоху раннего Средневековья было относительно второстепенным элементом христианства, становилось все более значимым, двигаясь к своему расцвету в эпоху позднего Средневековья [33, pp. 87-105, 237-268; 35, p. 341; 36, pp. 176-201]. Таким образом, Шартр, сделав ставку на выигрышную доктрину, стал одним из важнейших объектов паломничества в Западной Европе, а его собор - одной из главнейших святынь.

Отклик людей на постигшее их бедствие драматично описан в источнике той эпохи. В нем говорится, что кардинал Пизы, который проживал в то время в Шартре, убедил и религиозных лидеров епархии, и народное собрание, что собор следует восстановить. Во время его речи перед народным собранием священнослужители вынесли Священную Тунику, которая, по их словам, чудесным образом не сгорела в огне. В порыве религиозного энтузиазма священнослужители и граждане пообещали пожертвовать все средства, какие только возможно, на восстановление собора. Они также сами работали на восстановлении собора по многу часов бесплатно [34, pp. 161-178].

Несмотря на все эти усилия, возможности общины по финансированию проекта были исчерпаны через три года: Шартр был богатым городом, но количество его жителей не превышало 10 тысяч человек. Они были вынуждены просить о помощи. По всей Франции и за ее пределы были отправлены делегации священников с реликвиями, менее значимыми, чем Туника, чтобы они собирали пожертвования на продолжение работ. Королева Бланка, мать Людовика IX Святого, пожертвовала огромную сумму. Так же поступили и герцог Бургундский - союзник королевской фамилии и, возможно, богатейший французский

6 Южная башня (справа, если стоять лицом к фасаду), которая первоначально была отдельно стоящей, была в процессе реконструкции присоединена к фасаду. Она считается шедевром архитектуры за элегантное решение проблемы размещения восьмиугольного пронзающего небо шпиля на квадратном основании, стоящем на земле [33, pp. 62-68]. барон того времени, - и Ричард Львиное Сердце, хотя и находившийся в состоянии войны с Францией, и многие другие. Результатом этих усилий стало огромное, причудливо украшенное здание, считающееся самым величественным готическим собором в мире [33, pp. 87, 186; 34, pp. 178-182].

\section{Племя ик на севере Уганды}

Историю племени ик рассказывает известный антрополог С. Turnbull, который ранее изучал пигмеев из лесов Итури в Конго. По мнению ученого, пигмеи обожествляют эти опасные леса и черпают из них все, что необходимо для полноценной жизни [37]. Иначе обстоит дело с племенем ик. Изначально они были полукочевым племенем охотников, в поисках добычи перемещающимся между прилегающими районами северной Уганды, Кении и Судана. Большую часть года они проводили в плодородной, богатой дичью долине Кидепо в Уганде. После завоевания африканскими странами независимости их границы перестали быть столь прозрачными, как это было в бывших колониях, а затем Уганда объявила долину Кидепо национальным парком. Племя ик оказалось ограничено в своих передвижениях очень маленьким, самым гористым и наименее плодородным участком своей прежней территории. Охотничьих угодий стало совершенно недостаточно, а возделывание земли позволяло хоть как-то прокормиться только в те редкие годы, когда нет засухи [38, pp. 20-33].

Результатом, по свидетельству Turnbull, стала деградация народа ик. В попытках достать еду они начали попрошайничать, воровать, угнетать своих родителей, отнимать еду у стариков, и все это без малейших угрызений совести [38,pp. 151-154, 261]. Свои скудные поля они возделывали в одиночку, а урожай съедали сразу или прятали, оставляя свои традиционные зернохранилища пустыми. Если кому-то удавалось убить животное (часто незаконно), он не делился ни с кем, включая родственников, а пировал над добычей в одиночку, пока его не обнаруживал кто-то из членов племени [38, pp. 81-89]. Крохотные деревни ик были исчерчены соломенными изгородями, так что каждая семья могла передвигаться по узким коридорам без необходимости видеть других или общаться с ними [38, pp. 115-122]. Они игнорировали личную гигиену, испражнялись перед дверями соседей. В домах кишели вши и тараканы. Молодые девушки отдавались за еду 
как своим соплеменникам, так и пастухам из других племен, которые проходили через земли племени [38, pp. 254-255]. В таких тяжелых условиях они быстро теряли привлекательность и, если им не удавалось выйти замуж, часто умирали, не достигнув тридцати лет. Если же они выходили замуж и рожали детей, то этих детей отсылали из дома в возрасте трех лет, после чего те сами должны были обеспечивать себя [38, pp. 121, 135-138]. Turnbull описывает девочку, которая не смогла найти себе еду и вернулась к родителям. Родители заперли ее в жилище без еды и оставили так, пока она не умерла от голода, а затем выбросили тело на помойку [38, pp. 131-132].

Культура, которой ранее обладали ик, исчезла. Они не обращали внимания на свое священное дерево, и оно служило лишь мишенью для пастухов из других кочевых племен, которые бросали в него коровий навоз [38, pp. 62, 91]. Поскольку ранее традиции предписывали сопровождать свадьбы и похороны пиршествами, которые должны устраивать семьи вступающих в брак или умерших, то теперь свадьбы не празднуются, а похороны проводятся тайно, часто тело умершего просто засовывают в яму [38, pp. 85-86, 123-124, 130, 194-196]. Хотя члены племени по-прежнему изредка помогали друг другу в строительстве домов, они больше не охотились и не возделывали землю вместе. Большую часть времени они проводили, сидя на возвышенности неподалеку от деревни, глядя вдаль, либо игнорируя, либо задирая других [38, р. 87].

\section{Интерпретация примеров}

Каждый, кто когда-либо участвовал в групповом процессе принятия решений, например, в рабочем собрании, должен признать, что мотивации других людей бывает нелегко понять, даже если это члены одного и того же сообщества, имеющие близкое положение и работающие на одном предприятии. Если же перед нами стоит задача объяснить поведение таких отличных от нас людей, как куриалы, строители Шартрского собора или члены племени ик, то следует

\footnotetext{
7 Отчет Turnbull о племени ик заканчивается с завершением его книги в 1971 г. Более поздняя научная статья свидетельствует, что дальнейших исследований не проводилось [39] и, насколько мне удалось установить, не проводится до сих пор. Недавно вышел документальный очерк, согласно которому ик выжили, хотя и с трудом [40]; в материале не указано, осталась ли их культура той, которую описал Turnbull.
}

подходить к такой задаче с большой осторожностью. В частности, нужно преодолеть тенденцию приспосабливать их мотивацию к нашей, отбрасывать объяснения, которые кажутся нам неправдоподобными, и игнорировать не вписывающиеся в систему факты. Мы должны признать, что объяснение человеческого поведения - это вопрос интерпретации, со всеми сопутствующими сложностями, описанными современной философией, литературной критикой и социологией. Это проблема психологических рамок, которые определяют человеческое поведение, придают конкретный смысл наблюдаемым событиям и определяют выбор возможных действий в данной ситуации [41; 42; 43, pp. 113-197, 301-373; 44].

Из трех приведенных выше примеров бегство куриалов кажется самым очевидным в плане материальных интересов. Можно предположить, что бегство происходило в результате прекращения тех условий, которые обеспечивали исполнение служения в греческих городах. В тех напряженных и стесненных условиях, когда создавались эти города, состоятельные граждане не имели другого выбора, как только жертвовать средства на нужды города общественно приемлемым образом. Каждый, кто отказался это делать, был бы подвергнут остракизму, в результате которого его материальное положение ухудшилось бы ${ }^{8}$. Уход из города не мог рассматриваться как вариант действий. Но в римских колониях эти условия уже не были главенствующими, и куриалы могли уехать из города. Фактически они устранялись от своей общественной обязанности помогать своему городу, предпочтя личную выгоду. Это предпочтение показывает, что они были мотивированы своими материальными интересами.

Такое рациональное объяснение нельзя полностью отбрасывать, но ему противоречат эмпириче-

В А Афинах, печально известных склонностью жителей к сутяжничеству, ответчик в суде мог указать на свое аккуратное исполнение служения как на аргумент в свою пользу (поскольку правил доказательства не существовало). Более того, тот, кто должен быть исполнить служение, мог указать на другого гражданина, который обладает большим состоянием, но делает для города меньше, и заставить того выполнить служение за него [19, р. 229]. Очевидно, что такие механизмы принуждения делали служение менее добровольным, однако Афины, возможно, представляли собой исключение из правил, будучи гораздо более крупным и коммерциализированным городом, чем любой другой город материковой Греции. Важнее всего, что эти механизмы были основаны на этике долга. 
ские соображения. Во-первых, сами греки не так воспринимали служения. Состоятельные граждане греческих городов, конечно, стремились сохранить и приумножить свое богатство, а также в полной мере осознавали те общественные санкции, которые последуют за отказ жертвовать в пользу города. Но главным мотивом для них было желание приумножить свою честь, а не свое богатство; фактически они рассматривали богатство как средство сохранения чести, а не наоборот [19, p. $134 ; 42 ; 45 ; 46$, pp. 121-145]. Аргумент, что они были неискренни, автоматически показывает, что мы считаем материальную выгоду единственной мотивацией человеческого поведения и будем отвергать любую другую мотивацию.

Объяснение бегства куриалов с точки зрения рационального выбора не отражает не только их субъективного отношения, но и некоторых форм поведения. Городская элита восточной, т. е. греческой, части империи не уезжала из своих городов. Хотя они в той же мере находились под защитой раx Romana [28, pp. 42-45, 139-143; 29, pp. 25, 263-265] ${ }^{9}$. Как отмечает Peter Brown, в середине V в. христианские епископы часто защищали себя от обвинений в ереси с помощью того же аргумента, который афинские плутократы использовали в $\mathrm{V}$ в. до н. э., а именно что они «украсили город, построив акведук и галерею» [28, p. 44]. Возможно, это главная причина того, что восточная часть империи просуществовала намного дольше и не только смогла противостоять германским и славянским набегам, но и сохранила основные территории во время более внезапного и жестокого нашествия арабов ${ }^{10}$.

\footnotetext{
9 Разумеется, состоятельные люди на западе, как и на востоке, строили роскошные загородные виллы. Никогда не помешает иметь домик в деревне, если можешь себе это позволить. Но на западе, как и на востоке в более ранний период, люди использовали эти поместья как вторые дома, а не как средство уклониться от городской жизни.

${ }^{10} \mathrm{~B}$ отличие от арабов германские завоеватели не были особенно враждебны по отношению к романской цивилизации. Многие из них приняли крещение перед присоединением к империи, и почти все имели обширные экономические и культурные контакты с ней. После нашествия эти так называемые варвары, если еще не были христианами, быстро становились ими и считали себя преемниками римского правления. Арабы принадлежали к соперничающей религии, столь же сложной, как христианство. Они не обращались в христианство и считали, что заменяют римское правление на новую и более совершенную культуру [28, pp. 189-203; 29, pp. 279-297; 47, pp. 57-84; 48, pp. 81-82].
}

Проблемой западной части империи стало то, что городская форма правления была там чужеродной. В результате чувство принадлежности и преданности, которое греки испытывали по отношению к своим давно существовавшим и обладающим индивидуальностью городам, в колониальных городах романского Запада было значительно слабее. Эти искусственные образования не могли дать своим состоятельным гражданам те нематериальные преимущества, которые давали их оригиналы на востоке. Кажется более вероятным, что бегство куриалов было вызвано не столько материальными интересами, сколько нормативной системой, построенной вокруг определенного понятия о чести, связанного с ролью гражданина. Точнее говоря, материальная мотивация также присутствовала, но она была вторичной. Куриалы уезжали из городов, потому что их первичная мотивация становилась слишком слабой, чтобы уравновесить вторичную. Политический строй романского Запада, с установившимся миром в сельских местностях и все более унифицированной культурой, давал им возможность уехать; при этом нормативная причина остаться, в других обстоятельствах более сильная, в этом случае была подорвана чужеродным характером греческой модели и отсутствием романской альтернативы для ее замещения.

В отличие от бегства куриалов героические усилия по возрождению Шартрского собора, кажется, свидетельствуют о действиях в противоположном направлении, а именно о жертвовании материальным богатством ради религиозного рвения. Однако возможно, что такое поведение неверно описывать как альтруистическое. Люди, жертвовавшие собственными деньгами и временем для реконструкции собора, были движимы совершенно определенным желанием получить выгоду для себя, однако эта выгода заключалась в спасении их бессмертных душ. С их точки зрения, они максимизировали пользу, но не в отношении своего материального положения в земной жизни, т. е. никоим образом не в рамках теории рационального выбора. Таким образом, чтобы рассматривать их поведение и наше в рамках единой системы, следует признать не то, что все люди руководствуются материальными интересами, а то, что все они мотивируются нормами; наши нормы - материальны, а их нормы были связаны с религиозностью.

На самом деле вполне возможно связать поведение прелатов и простых горожан Шартра с их 
стремлением максимизировать свои материальные интересы. Поскольку в эпоху позднего Средневековья культ Марии достиг своего расцвета, Шартр стал крупнейшим центром паломничества, и к концу XII в. в нем проходили четыре крупные торговые ярмарки (по числу церковных праздников, связанных с Девой Марией $)^{11}$. Разрушение собора поставило под угрозу исчезновения эти высокодоходные мероприятия, а его реконструкция рассматривалась как необходимое условие для поддержания превосходства и благосостояния города [34, pp. 164-169]. Нет сомнений, что все жители Шартра это прекрасно понимали, и, скорее всего, это было одним из мотивирующих факторов. Однако, прежде чем признавать выгоду в качестве основной мотивации, следует признать, что это в первую очередь наша собственная мотивация и что никто в нашем обществе, каким бы религиозным человеком он ни был, не верит в Бога так, как верил практически каждый в эпоху Средневековья. И снова, интерпретируя поведение людей на основе максимизации материальной выгоды, мы игнорируем их собственные мотивы поведения. Они сами не только с негодованием отвергли бы точку зрения, что их религиозное рвение по восстановлению собора было лишь ширмой материальных интересов, но и, вероятно, считали свое благосостояние, возникшее в результате паломничества и ярмарок, знаком божьей милости, наряду с источником дохода.

Как и в случае с куриалами, экономическая интерпретация восстановления собора представляет собой эмпирические трудности. Если завершение восстановления собора считалось необходимым условием для возрождения уровня паломничества и ярмарок, то горожане должны были понимать, что они не доживут до того момента, когда их жертвы начнут окупаться. Считается, что реконструкция Шартрского собора была проведена очень быстро, чем и объясняется цельность его архитектурного стиля, однако возведение боковых стен потребовало около 30 лет, а полная реконструкция - 60. Ни один взрослый, участвовавший в первых действиях по реконструкции, не дожил до ее завершения и не мог рассчитывать на то, что доживет.

${ }^{11}$ Кроме Рождества Богородицы, эти праздники включают Введение во Храм, или Сретение (2 февраля), Благовещение (25 марта) и Успение Богородицы (15 августа).
Деятельность, основанная на собственной выгоде, имеет тенденцию быть краткосрочной даже в наши дни из-за рационального обесценивания; несомненно, процент обесценивания в Средние века был значительно выше, с учетом меньшей продолжительности жизни и большей политической нестабильности. Можно ли поверить, что люди, ищущие материальной выгоды, посвятят пресловутые «лучшие годы своей жизни» деятельности, которая принесет выгоду только следующему поколению? Даже если их вынудили это сделать, почему они не построили что-нибудь попроще, закончили побыстрее, создав тем не менее вполне приемлемое хранилище для Священной туники, которая была, очевидно, главным «магнитом» для паломников и торговцев? Вместо этого они затратили гигантские физические усилия и художественное мастерство, создав огромное здание с многочисленными скульптурами, цветными витражами, признанное одним из шедевров мировой архитектуры. Кроме того, на восстановление собора жертвовали люди со всей Франции и из других стран. При этом многие из них, напротив, могли бы получить выгоду в случае упадка Шартра и переноса торговли в их местности, а другие, как, например, король Ричард, вообще не почувствовали бы никакой разницы.

Пример с деградацией племени ик, на первый взгляд, подтверждает как универсальность материальной мотивации, так и разрушительность ее последствий. Лишенные в результате политических перемен практически всех средств к существованию, они, кажется, дали рациональный ответ, отвергнув всю этику и эстетику в отчаянной попытке выжить. В то время как в литературе по общественным нормам в рамках теории рационального выбора уделяется огромное внимание попыткам объяснить кооперативное или альтруистическое поведение в терминах личной материальной выгоды, племя ик, кажется, считает эти попытки совершенно ненужными. Столкнувшись с необходимостью выживания в суровых условиях, они откровенно отбросили те нормы, которые управляют более благополучными сообществами, что означает, что эти нормы - роскошь, и в таком понимании их легче как объяснить, так и отвергнуть. Turnbull также склоняется к такой интерпретации. Его беспристрастное описание заканчивается почти истерическим высказыванием о том, что состояние общества, похожее на нынешнее положение племени ик, ждет всех нас, 
если мы забудем об ограничениях, существовавших веками [38, pр. 287-295]. Материальные интересы, говорит он, - это единственная настоящая мотивация, это скелет, который открывается после того, как моральная деградация сорвет все внешние покровы.

Такая интерпретация поведения членов племени ик кажется само собой разумеющейся, и, возможно, они и сами считают так же, хотя Turnbull не совсем ясно высказывается на эту тему. Однако вызывают вопросы некоторые детали его рассказа, на которых сам автор не заостряет внимания. Через год после завершения его первого исследования он вернулся в деревни ик и обнаружил, что необыкновенно сильные дожди позволили племени вырастить обильный урожай [38, pp. 268-270]. Однако «все посевы на всех полях гнили из-за полного небрежения... Повсюду были личинки и гусеницы, некоторые поля были разорены бабуинами» [38, p. 269]. Вместо того чтобы проводить больше времени на полях, люди продолжали сидеть на возвышении, не обращая внимания друг на друга или ссорясь. Они объяснили свое поведение тем, что на тот момент у них достаточно еды и нет смысла прилагать дополнительные усилия. Но если материальный интерес заставлял членов племени быть настолько безжалостно жестокими друг к другу во время голода, можно предположить, что та же самая мотивация заставит их произвести максимальное количество еды в более благоприятное время, сделав запасы в виде продуктов или денег. То, что они не делают этого, показывает, что они деморализованы, в обоих значениях этого термина. Они потеряли мораль, но, что более важно, они потеряли мотивацию. Это маленькое племя с довольно рудиментарной культурой, которая была тесно связана с их перемещениями и физическим окружением. Полное разрушение модели миграции и отторжение от охотничьих угодий нанесло смертельный удар по их способности поддерживать функционирование общества.

Анализ показывает, что эгоистичное, жестокое, сокращающее продолжительность жизни поведение членов племени ик совсем не является максимизацией собственных материальных интересов. Такая интерпретация будет лишь отражением нашей собственной культурной ориентации, а кроме того, гнева по отношению к себе за то, что допустили это, а отсюда желание представить такое общество как полностью дисфункциональное, как и делает Turnbull. Очевидно, что в интересах племени ик было бы сотрудничать друг с другом в решении различных задач. В прошлом у них была такая общественная норма, но затем она стала рудиментарной, оставшись лишь в смутном ощущении, что за услуги нужно платить. Именно этого ик стараются избежать, возводя стены и занимаясь охотой и сельским хозяйством в одиночку, чтобы никто не мог оказать услугу. В литературе по общественным нормам делаются попытки объяснить, как личные интересы порождают сотрудничество в культуре.

Главная идея состоит в том, что общественные нормы заставляют людей преодолеть желание подсчитывать непосредственную выгоду и начать работать совместно для максимизации своего благосостояния в долгосрочной перспективе. Например, James Coleman [17, pp. 309-310] отмечает наблюдение Turnbull о том, что ик иногда оказывают помощь члену племени против воли последнего, и делает вывод, что тем самым они в легкое время создают обязанность, за которую можно будет потребовать компенсацию в более тяжелый период. На самом деле нельзя спрогнозировать, как будет развиваться эта норма, а в данном случае объяснение Coleman неубедительно, потому что велика вероятность, что должник не доживет до момента, когда у него потребуют отдать долг. Представляется более правдоподобным, что люди, оказывающие непрошеные услуги, на самом деле просто жестоки, им нравится неудобство, которое должник будет чувствовать как во время ее оказания, так и позже, когда не сможет за нее отплатить. То, что не позволяет людям ик сотрудничать, когда это принесло бы пользу всем, - это не материальный интерес. Это жестокость, злоба или обида на каждого свидетеля их изгнания из прежних мест обитания и крушения их прежнего образа жизни.

Другими словами, нормы сотрудничества не являются отражением материального интереса. Это нормы. Они функционируют по-разному в различных обществах, в зависимости от того, как они вписываются в нормативную структуру этих обществ. В нашем обществе они действительно служат в качестве способов противостоять краткосрочным личным интересам, поскольку максимизация личных интересов превалирует в нашем обществе. В древнегреческом обществе, а также некоторое время в Римской империи они служили средством поддержания городской 
культуры и повышения чувства достоинства отдельного гражданина, выражаясь, в частности, через служения, или частное спонсорство общественных функций. В средневековой Европе нормы сотрудничества служили для поддержания религиозных институтов и поддерживали веру людей в личное спасение. Общественные нормы племени ик были разрушены не потому, что члены племени преследовали только материальные интересы или были такими недальновидными, а потому, что они начали ненавидеть друг друга, а возможно, и самих себя.

МАКСИМИЗАЦИЯ ЛИЧНОЙ МАТЕРИАЛЬНОЙ ВЫГОДЫ КАК ГОСПОДСТВУЮЩАЯ НОРМА СОВРЕМЕННОГО ЗАПАДНОГО ОБЩЕСТВА

Хотя модель максимизации личной материальной выгоды не слишком хорошо объясняет поведение людей во многих сообществах, для нашего общества она вполне приемлема. Она позволила достичь понимания современного западного мира. В данной части работы мы объясняем, почему успешность этой модели для достижения понимания нашего общества не означает, что эта модель универсальна для всего человечества, и почему общественные нормы должны рассматриваться не как добавочные элементы модели, а как основные элементы системы, в которой действует модель. Как и в вышеприведенных примерах, это объяснение частично опирается на культурные различия между нашим и другим обществом. Если в предыдущей части работы рассматривался преимущественно культурный контекст, то теперь мы сосредоточимся на исторических аспектах. То есть изучение исторического развития нормы материальной выгоды в нашем обществе не только показывает, что эта норма не является исключительной, но и выявляет конкретные исторические тенденции, в результате которых она появилась и которые в других обществах не проявлялись или действовали по-другому.

Если мы рассмотрим историческое развитие нашего современного общества, мы увидим, что наша убежденность в закономерности поведения, направленного на максимизацию личной выгоды, - это сравнительно недавнее приобретение. Еще в начале современной эпохи получение процентов за заем считалось серьезным преступлением; предполагалось, что все цены назначаются по справедливости, а не определяются рынком; производительность труда ремесленников и их рабочие часы устанавливались гильдиями; погоня за прибылью вызывала подозрения или прямое осуждение [10; 49; 50; 51, pp. 323-329]. Явное утверждение этих принципов звучало регулярно, практически не встречая несогласия. В основе этих принципов лежала религиозная идеология, доминирующая в дискурсе той эпохи, особенно в том, что касалось правил общественного поведения. Как отмечает Tawney, еще в конце XVII в. всеобщее убеждение, выраженное архиепископом Уильямом Лодом, гласило, что «личный интерес, который заставляет человека стремиться к богатству и продвижению» - это демон, которого необходимо изгонять [10, p. 146]. Контраст с современными нормами очевиден. Это значительное отличие господствующих верований и системы ценностей наших предшественников и современного общества.

В историографии западного общества долгое время ведутся дискуссии о возникновении так называемого духа капитализма. Weber [9] и Tawney [10] приходят к выводу, что решающим фактором выступил кальвинизм, следовательно, поворотным моментом была протестантская реформация. Как описывают эти и другие авторы, например, E. Troeltsch [52], дух капитализма не полностью эквивалентен максимизации личной материальной выгоды. Например, Weber характеризует его как «мирской аскетизм» и связывает с тяжелым трудом, самоотверженностью и предостережениями Бенджамина Франклина против траты времени, т. е. понимает его не просто как желание накопить материальные богатства [9, pp. 14-22, 53-101]. Многие люди, настроенные в более психологическом, эстетическом и сибаритском ключе, возразят, что такая безрадостная жизнь не может отражать ничьих личных интересов. Однако если мы признаем, что микроэкономическая теория и ее политический аналог - теория общественного выбора - основаны не просто на проблеме личной выгоды, а на проблеме материальной выгоды, то разница между ними резко сократится. Аскетизм, описанный Weber, - это убедительная, вероятно, лучшая стратегия максимизации материального положения. Таким образом, хотя, возможно, и нельзя сказать, что все, кто стремится максимизировать свою материальную выгоду, ведут себя как современные капиталисты, но представляется верным считать, что современные капиталисты склонны рациональным образом максимизировать свою материальную выгоду. 
Это впечатляющая теория, но в связи с данным исследованием она вызывает ряд вопросов. Вопросы эти не эмпирические; хотя взгляды Weber и Tawney и подвергались критике, они все же продержались целое столетие. Один из трудных вопросов - почему Кальвин оказал такое значительное влияние, которое приписывают ему Weber и Tawney. Учитывая, что он не обладал никакой прямой властью ${ }^{12}$, его влияние зависело целиком от убедительности его работы. Разумеется, эта работа носила в основном богословский характер. Хотя проницательность Кальвина привела его к выводу, что предоставление денег под разумный процент полезно с точки зрения экономики, однако в целом он относился к коммерции с таким же пренебрежением, что и остальные христианские авторы, поэтому все экономические выводы из его трудов появились в результате активной интерпретации другими людьми [10, pp. 145-149, 177-180; 51, pp. 329-343]. Еще одна, более серьезная проблема состоит в том, что кальвинизм, даже с учетом его самой широкой интерпретации, твердо одобряет тяжелый труд и бережливость, но накопление богатства само по себе лишь извиняет. Кальвиниста привел бы в ужас блестящий изобретатель, сделавший состояние на неожиданной гениальной догадке, а затем проводящий остаток жизни в праздной роскоши. Этика максимизации личной материальной выгоды рассматривает стремление к богатству как неотъемлемый двигатель благосостояния, а изобретателя на покое - как справедливо получившего право на отдых в результате высокой рыночной ценности внесенного им вклада.

Как бы ни было оригинально и интересно приписать современную концепцию максимизации богатства строгим и набожным кальвинистам, лучше все же рассматривать ее как кульминацию более глубоких и более знакомых нам общественных тенденций: коммерциализации, политической концентрации и секуляризации. Хотя ни торговля, ни ремесла не исчезли в эпоху раннего Средневековья (800-1000 гг. н. э.), уровень коммерческой активности был значительно ниже, чем во времена поздней Римской империи

12 Точнее говоря, он был религиозным лидером довольно своеобразной теократии в составе маленького европейского княжества - Женевы, - но получил он эту должность только благодаря приглашению гражданских властей [53, с. 57-59; 54, c. 121-125]
[29, pp. 529-551; 48; 55, pp. 103-111; 56]; позднее этот уровень стабильно повышался. Рост частично подпитывался стремлением к богатству, характерным для периода перед Реформацией, но, как минимум, в той же степени желанием свободы, поскольку города представляли собой единственное спасение от феодальной системы, где неблагородные сословия могли быть свободными [55, pp. 126-148; 57, pp. 106-132; 58, pp. 199-210; 59; 60], а добывать себе пропитание и одежду горожане могли только с помощью коммерции. Параллельной и взаимодействующей тенденцией было возрождение централизованного управления. Короли могли даровать городам хартии, которые закрепляли свободы их жителей, и тогда города становились естественными союзниками монархов в их многовековой борьбе с лордами, которые преимущественно были феодалами и занимались сельским хозяйством [57, pp. 167-196; 61, pp. 81-166]. Если монарх одерживал победу над лордом, то разоружал его и превращал в придворного; при этом его земли переходили под юрисдикцию короля, что давало дополнительное преимущество в виде развития коммерции [62, pp. 441-475; 63, pp. 275-311]. Эта развивающаяся коммерция затем служила источником доходов короля и его растущих политических амбиций, что в свою очередь создавало потребность в дополнительных средствах, а значит, еще один повод поддерживать города и распространять власть на сельские районы.

Параллельный процесс секуляризации, с одной стороны, слишком сложен, а с другой - слишком хорошо известен, чтобы подробно излагать его в данной работе. Достаточно отметить, что после распада Римской империи Западная Европа осталась с единой церковью и раздробленными политическими режимами ${ }^{13}$. После 1000 г. это противоречие породило неизбежную напряженность между церковью и обладающими централизованной властью монархами, и монархи, как и в случае с лордами, постепенно одерживали

\footnotetext{
${ }^{13}$ В течение краткого исторического периода Карл Великий управлял большей частью западного христианского мира и был коронован в качестве императора Папой; в это время восстановление единой политической и религиозной власти было, казалось, возможно. Однако империя Карла Великого в IX в. распалась, а имперская корона перешла к одной из ее частей, примерно соответствующей территории современной Германии, которая затем стала одной из самых решительных противников папства.
} 
верх. Интеллектуальное движение, позднее получившее название «Ренессанс», в некоторой степени ослабило влияние христианства на умы людей, и еще большее влияние оказала на них эпоха потрясений между 1309 и 1418 гг. (Авиньонское пленение Пап, когда церковь управлялась французской монархией, и Великий раскол Западной церкви, когда два или более человек одновременно заявляли, что они Папы) [64, pp. 288-304; 65]. Первоначально Реформация, казалось, ознаменовала возрождение религиозного чувства, но в долгосрочной перспективе результатом стал раскол институционального христианства, еще сильнее поставивший обе вновь образованные протестантские церкви и истощенную католическую церковь под контроль государственной власти, а также рост сомнений в истинности христианской доктрины $[66,67]$. Знакомство Европы с нехристианскими культурами в XVI-XVII вв., а позднее научная революция еще больше подорвали религиозную доктрину и веру. K XVIII в. скептицизм и светские взгляды стали превалировать [68], а к XIX-XX вв. они стали господствовать $[69,70]$.

Действуя непрерывно, эти тенденции медленно подрывали религиозный, направленный на идею спасения образ мышления, который превалировал на христианском Западе, и подготовили почву для современного взгляда на закономерность и ценность максимизации личной материальной выгоды. Ключевой фигурой этого перехода, тем человеком, который с определенностью отверг средневековые представления и четко сформулировал современные, был именно тот, кому и приписывают эти заслуги, - A. Smith. Важно, однако, определить значение его работы в контексте и в ретроспективе. Как подчеркивают современные ученые, сам Smith был скорее специалистом в области этики, чем экономики [71, pp. 204-210; 72, pp. 35-38, 53-70]. Это так не только потому, что одна из его важнейших работ называется «Теория нравственных чувств» [73], но и потому, что «Богатство народов» [74] также говорит об этике. Эта работа была написана после выхода произведения В. Mandeville «Басня о пчелах». В начале XVIII в. Mandeville опубликовал стихотворение «Возроптавший улей, или Мошенники, ставшие честными» (The Grumbling Hive, or Knaves Turn'd Honest), которое затем вошло как составная часть в более длинное произведение «Басня о пчелах, или Пороки частных лиц - блага для общества» (Fable of the Bees, or Private Vices, Public Virtues) [75]. Как видно из названия, Mandeville доказывает, что эгоистичное, меркантильное поведение, осуждаемое моралью, приводит к общественному благу [75, pp. 24-25]:

Пороком улей был снедаем, Но в целом он являлся раем... Здесь жадность, будучи истоком Всех зол, губительным пороком, Себя связала с мотовством Сим благороднейшим грехом; Здесь роскошь бедных выручала Тем, что работу им давала; Ей гордость в этом помогала; А зависть и тщеславье тут Облагораживали труд. (Перевод Е. С. Лагутина)

Сам Mandeville был реформатором общества, но также принадлежал к группе мыслителей XVIII в., которые с удовольствием высмеивали традиционную религию и мораль. Когда была опубликована эта работа, моралистическое отношение к коммерции все еще преобладало настолько, чтобы послужить основой для всеобщего осуждения его взглядов. Smith предлагает более комплексную и глубокую версию догадки Mandeville, переводя ее из области сатиры в область экономической науки. Кроме того, он в значительной мере переформулирует взгляды Mandeville на мораль. Эгоистичное, или, как бы мы сказали сегодня, основанное на материальных интересах, поведение не является злом, которое, согласно Smith, парадоксальным образом приводит к общественному благу. Он не заходит так далеко, чтобы назвать его добродетелью, поскольку находится еще слишком глубоко в рамках традиционного общества, но описывает его как естественное поведение, как рациональный и безукоризненный поиск собственных интересов, который оправдан прекрасными результатами, к которым он приводит. «Не от благожелательности мясника, пивовара или булочника ожидаем мы ужина, а от их заботы о своем собственном интересе. Мы обращаемся к себе, не к их гуманности, а к их эгоизму...» [74, p. 119]. В XVIII в. естественность во многом приравнивалась к добродетели, по крайней мере в квазинравственном смысле, и тем самым 
Smith начал современную традицию рассматривать рациональное стремление к удовлетворению своих интересов как доминирующую норму.

По меньшей мере кажется очевидным, что западное общество не считало максимизацию личной материальной выгоды приемлемой формой поведения вплоть до конца XVIII в. Конечно, вполне можно доказать, что превалирующие социальные нормы до современной эпохи не влияли на поведение, что в те времена, как и сейчас, люди мотивировались материальными интересами. Однако такие утверждения сталкиваются с некоторыми значительными трудностями. Во-первых, они подразумевают, что превалирующие социальные нормы могут существовать продолжительное время, в данном случае по крайней мере восемьсот лет, не оказывая никакого влияния на поведение. Во-вторых, они игнорируют широкий спектр общественных практик, которые противоречат максимизации материальных выгод, пытаясь объяснить их в терминах институциональных ограничений, которые сами нуждаются в объяснении. В-третьих, и это главное, поскольку это наши нормы, мы должны признать, что будем пытаться объяснить поведение людей в этих терминах, что мы будем рассматривать наиболее позднюю форму поведения как правильную, а другие - как отклонения от нее и что мы будем искать другие мотивации для объяснения поведения тех, кто явно придерживался прежней нормы.

Кроме всего прочего, имеется важное косвенное свидетельство того, что работа Smith отражает настоящую трансформацию норм в обществе. Конец XVIII в. был эпохой глобальных изменений. В это время произошли две крупные революции, в Америке и во Франции, а также переход к демократической системе правления в Америке в результате этой революции и в Британии в результате развития парламентаризма, стимулированного, по иронии истории, той же революцией ${ }^{14}$. Тогда же появилось административное управление современного типа не только в Америке

\footnotetext{
${ }^{14}$ Когда в 1782 г. лорд Норт подал в отставку с поста премьер-министра из-за невозможности подавить выступления в тринадцати колониях, все остальные министры подали в отставку вместе с ним, что было первым таким случаем в истории. Это означало, что они являлись не министрами короля, а членами избранного правительства, которое действовало или не действовало на основе доверия избирателей.
}

и Франции после революций, но и в Британии в результате реформ Питта, в Австрии - благодаря усилиям «великодушного деспота» - императора Иосифа II, в Пруссии - в результате реформ Штейна и Гарденберга, поддержанных не столь великодушным деспотом Фридрихом-Вильгельмом III [76, pp. 22-36]. Можно сказать, что в тот же период началась промышленная революция, хотя ее преобразующее влияние проявится лишь через несколько десятилетий. Все эти изменения имеют отношение и к нормативным рамкам максимизации личной материальной выгоды. В конечном счете демократия основана на предпосылке, что государственную политику должны определять люди, голосующие в своих собственных интересах, а не монарх, который действует от их имени, самостоятельно решая, что является для них благом. Предполагается, что задачей административного управления является обслуживание материальных потребностей людей, обеспечение экономического процветания и общественного блага через разумно разработанную политику ${ }^{15}$. Предприниматели, свободные от традиционных ограничений и нацеленные на получение максимально возможного богатства, не только возглавили промышленную революцию, но и смогли благодаря ей получить это богатство, апеллируя к материальным желаниям простого народа.

Итак, максимизация личной материальной выгоды стала превалирующей нормой западного мира в конце XVIII в. Ее происхождение можно проследить до хорошо известных политических, общественных и интеллектуальных тенденций, а ее подъем связан с подобными же движениями в других сферах общественной жизни. Эти тенденции и движения уникальны; ни одно другое общество не прошло через те же процессы коммерциализации, национализации и секуляризации, ни в одном другом обществе не возникла массовая демократия, административное управление и индустриализация, кроме как под влиянием западной культуры. Это дополнительное доказательство того, что данная норма является специфической чертой нашего общества, а не универсалией для всего человечества. Изучая другие общества, такие как Древний Рим, средневековая Европа или племя

15 Я рассматриваю этот аргумент в двух книгах: «Beyond Camelot» («За пределами Камелота») [76] и «Soul, State and Society» («Душа, государство и общество») (в печати). 
ик, мы видим, что нельзя интерпретировать поведение членов других сообществ как мотивированное в первую очередь максимизацией личной выгоды. Изучая наше собственное общество, мы замечаем, что поведение его членов можно интерпретировать указанным образом, но это отражает лишь конкретные результаты его развития, подчеркивающие его уникальность. Коротко говоря, максимизация личной материальной выгоды сама по себе является нормой. Мы придерживаемся ее и делаем это в такой значительной степени потому, что это наша норма, но не потому, что она заложена в генетической программе человечества.

\section{ПРЕВАЛИРУЮЩИЕ НОРМЫ И ЛИТЕРАТУ - РА В ОБЛАСТИ ОБЩЕСТВЕННЫХ НОРМ}

Как уже говорилось, современная микроэкономическая теория признает роль общественных норм и старается учитывать их при анализе рационального выбора. Мы, однако, считаем, что именно нормы являются превалирующим элементом в отличие от рационального выбора и что максимизация личных материальных интересов, т. е. поведение, лежащее в основе рационального выбора, является отдельной нормой, превалирующей в нашем обществе. Но если это так, то каков статус тех норм, которые рассматривает микроэкономический анализ, и как они соотносятся с этой значимой нормой, которая определяет поведение, направленное на максимизацию своей выгоды? Мы считаем, что по крайней мере некоторые из этих норм отражают другие аспекты нормативной структуры общества и проявляются в экономической деятельности, когда превалирующая норма по той или иной причине не может полностью определять действия людей.

Если считать, что норма - это правило, которое не устанавливается законом, но тем не менее исполняется [3], тогда большую часть действий, совершенных под влиянием норм, как и большую часть законопослушных действий, можно объяснить с точки зрения модели рационального выбора действующего субъекта. С точки зрения рационального выбора несложно объяснить, почему современные европейцы, в отличие от людей раннего Средневековья, не пользуются оружием при решении проблем с недвижимостью; стоит только вспомнить о неизбежном суровом наказании, которое современное государство наложит на нас за подобное поведение. Такие же суровые наказания могут быть наложены и неофициальными, неюридическими действующими лицами. Например, если все члены некоего коммерческого сообщества - торговцы бриллиантами или театральные продюсеры - не станут иметь дело с человеком, ведущим себя определенным образом, то ни один рациональный действующий субъект, желающий работать в этой сфере, не будет вести себя таким образом, если только не считает, что сможет избежать наказания [77-80]. Другими словами, некоторые виды поведения, определяемого нормами, вырабатываются внутри структуры максимизации материальных выгод, и для них не требуется обращения к каким-либо другим нормам.

Существуют, однако, и другие виды поведения, определяемого нормами, которые не так легко объяснить. Один из таких видов поведения возникает, когда наказание мало или его вообще нет. В литературе по микроэкономике, посвященной общественным нормам, описываются такие случаи, например, как нормы, обязывающие участвовать в выборах или давать чаевые за некоторые услуги [5, 81-83]. Сложнее объяснить, почему люди, если они действительно стремятся максимизировать личную выгоду, не уклоняются от исполнения таких норм чаще [84, 85], т. е. почему общественные нормы могут сохраняться так долго. Часто в ответ на оба этих очевидных противоречия выстраивают ошибочные логические цепочки, показывающие, что исполнение нормы на самом деле имеет под собой рациональную основу: например, что чаевые поощряют лучших работников или что экономика будет работать лучше, если поддерживать нормы честной игры и доверия. Однако такой подход оставляет многое без объяснений. Сила микроэкономической теории состоит в ее твердой опоре на методологический индивидуализм, в убеждении, что коллективные формы и результаты взаимодействия должны объясняться в терминах поведения отдельных индивидов [17, pp. 1-23], а не в ссылках на туманные постулаты и концепции, которые красиво звучат на немецком, такие как zeitgeist (дух времени), weltanschauung (мировоззрение) или gessellschaft (единство). С этой точки зрения, однако, становится сложно объяснить, почему люди, заинтересованные лишь в увеличении собственной материальной выгоды, участвуют в деятельности, приносящей лишь коллективную, а не личную выгоду $[82,86]$. 
Предпринималось немало попыток объяснить эти факты, но все они только усложняют вопрос. Мы не хотим сказать, что все они неверны; многие из этих попыток хорошо объясняют, почему общественные нормы действуют, особенно в экономических ситуациях. Трудность здесь снова эпистемологическая; эти объяснения обнаруживают те же недостатки, что и попытки объяснить бегство куриалов, реконструкцию Шартрского собора или бедствия племени ик в терминах максимизации материальной выгоды. Это отчаянные попытки приспособить к нашим господствующим нормам поведение, основанное на других мотивациях. Они производят такое же неприятное впечатление, как доктор, ставящий один и тот же диагноз всем пациентам независимо от их симптомов, а именно диагноз той болезни, в которой этот доктор специализируется.

Альтернатива этому та же, что и альтернатива в трех вышеприведенных примерах. В них самым правдоподобным, или, можно сказать, самым экономически целесообразным, подходом будет объяснение наблюдаемого поведения в терминах других общественных норм, таких как честь, религиозная вера или мстительность. Тем самым мы отбрасываем обусловленный всей нашей культурой вывод, будто все человеческое поведение основано на максимизации личной материальной выгоды, однако при этом сохраняется более обоснованная эпистемологическая установка методологического индивидуализма. Альтернативные нормы испытываются и в большинстве случаев принимаются отдельными действующими лицами не в результате расчетов, а через тот процесс, который Гуссерль назвал интерсубъективностью [87, pp. 93-95, 388-390; 88, pp. 252-257]. Это означает, говоря очень приближенно, что нормы познаются на самом базовом уровне, на котором человек учится функционировать как член данного общества, а также что единственным способом для человека понять правила поведения и когерентного мышления в обществе остается инкорпорирование конкретных норм в свою систему верований.

Против такой точки зрения выступает J. Coleman [17], приводя в доказательство теорию протестантской этики Weber [17, pp. 6-10]. Желая доказать, что макроэкономические общественные условия могут порождать или влиять на индивидуальные предпочтения людей, он оспаривает, что индивидуальные предпочтения, проявляющиеся на микроуровне, могут объединяться, порождая общественные условия, и утверждает, что всякое такое объяснение должно опираться на институциональные принципы, т. е. должно показать, как отдельные люди повлияли на конкретное общественное действующее лицо и как это действующее лицо затем повлияло на общество в целом. Все это звучит очень строго, особенно с учетом присущей Coleman безапелляционности. Однако все эти построения не выдерживают анализа, поскольку выдают за постулат то, что он хочет доказать, а именно что индивидуальные предпочтения не могут объединяться, порождая общественные условия. Coleman пытается показать механизм, с помощью которого будет происходить этот процесс, но в своем исследовании он отвергает тот механизм, который мы описываем в данной работе и который признают большинство ученых в области общественных наук. Это некая разновидность интерсубъективности, идея о том, что индивидуальные предпочтения, включая нормы и соответствующие толковательные или эпистемологические взгляды на природу вещей (которые мы в целом называем описаниями), структурируют возможности для общественного действия, тот спектр поведенческих реакций, которые может выбрать любой индивид, и значение этих реакций для себя и других членов общества ${ }^{16}$.

Неправдоподобность аргументации Coleman можно продемонстрировать с помощью мысленного эксперимента. Если группу людей из определенного общества поместить на отдаленный, но обитаемый остров, то невозможно представить себе, что общество, которое они там создадут, будет соответствовать только превалирующим условиям, никак не отражая какие-то принципы их первоначальной культуры. Этот эксперимент проводился лишь несколько раз и в малых масштабах, например, на острове Питкэрн; однако примеры колоний в Северной Амери-

\footnotetext{
${ }^{16}$ Отличительная черта обширного и во многом информативного исследования Coleman - это его абсолютное нежелание иметь дело с кем-либо из многочисленных и хорошо известных современных мыслителей, выступающих в поддержку общественного конструктивизма. Из всей этой литературы, прямо противоречащей теории Coleman, мне удалось найти в его работах лишь одно краткое упоминание Хабермаса по незначительному поводу $[17$, p. 636].
} 
ке, Австралии и Южной Америке (т. е. там, где не наблюдалось значительного смешения пришлых и местных культур) показывают, что индивидуальные предпочтения будут определять культуру даже в отсутствие институциональных структур.

В случае с нашим обществом самая правдоподобная причина, по которой люди не всегда действуют с целью максимизации своих материальных интересов, состоит в том, что в обществе, кроме одной господствующей, или превалирующей, нормы действуют и другие нормы, в том, что разные сферы жизни управляются различными нормами, перетекающими одна в другую. Существование таких норм ставит под сомнение теорию рационального действующего лица $[5,89,90]$. Эта множественность мотиваций может показаться неправильной сторонникам микроэкономической модели или тем, кто считает, что все поведенческие теории универсальны. Но если тип поведения, на котором зиждется эта модель, является сам по себе нормой, а не универсалией для всего человечества, как это было показано выше, то ссылка на одну норму ничем не хуже, чем ссылка на любую другую. Другими словами, если мы признаем, что рациональная максимизация личной материальной выгоды - это специфическая норма нашего общества, то нет причин, почему мы не можем иметь также и другие нормы, и нет причин, почему ссылка на эти другие нормы будет менее удовлетворительной для обоснования поведения человека, чем ссылка на господствующую норму.

Фактически вполне очевидно, что в нашем обществе существуют нормы, отличные от максимизации личной материальной выгоды, как бы ни была важна и значима эта норма. Чтобы показать это, достаточно двух коротких примеров. Хотя современный западный мир более коммерциализирован, т. е. больше ориентирован на экономику, чем мир средневековой Европы, однако нормы, относящиеся к браку, развивались в противоположном направлении. В Средние века браки представляли собой экономические союзы, будь то две знатные семьи, объединяющие свои владения, или дворянин с хорошей родословной, женящийся на купеческой дочке с хорошим приданым, или крестьянка с лошадью, выходящая замуж за крестьянина с телегой [91, pp. 88-122; 92; 93; 94, pp. 214-220]. Это было не только прагматичной сделкой, но и общественной нормой. Католическая церковь утверждала, что брак должен основываться на согласии, вот только родители могли получить это согласие от детей (или взрослый мужчина мог получить его от родителей двенадцатилетней девочки), а затем опираться на господствующие нормы, чтобы обеспечить его выполнение [92, 95]. В современном мире, где идея о справедливой цене вызывает насмешку, а цеховые ограничения считаются предрассудком, люди женятся по любви $[91,96]$. Это не значит, что они никогда не принимают во внимание экономические факторы, однако существует сильная общественная норма, направленная против выбора брачного партнера на этой основе.

Второй пример приводит судья Познер. Очевидно, что позиция, состоящая в поддержке промышленного производства, отвечает личным материальным интересам многих ученых, особенно в тех областях права, политологии, экономики и социологии, где существуют противоречивые точки зрения. Такая позиция помогла бы им получать гранты, давать высокооплачиваемые консультации, устроиться на выгодные должности, помимо научной карьеры. Кроме того, в некоторых случаях они могли бы получить должности в научном мире, привлечь финансирование в свои университеты, получить за это льготы со стороны руководства. Однако сильные общественные нормы требуют от ученых объективности. Конечно, некоторые ученые могут и пожертвовать объективностью ради материальной выгоды, но мало кто из них признает это открыто, что и доказывает существование жесткой общественной нормы.

Другими словами, хотя максимизация личной материальной выгоды и является господствующей нормой в нашем обществе, это не единственная норма. Разумеется, она определяет значительную часть поведения, но, поскольку это лишь норма, а не универсальная модель поведения человека, она может быть изменена или поглощена другими нормами, если условия будут способствовать этому. Таким образом, поведение, не укладывающееся в рамки рационального выбора, не следует считать таинственным уходом в область иррациональности. Напротив, оно представляет собой естественное взаимодействие разнообразных мотивов, существующее в любом сложном обществе, а источниками такого поведения будут все события повседневности. Современный человек, которые отвергает советы о выгодной женитьбе, вместо этого вступая 
в брак по любви, может затем пойти работать в банк, пожертвовав семьей. Ученый, который ведет работу с твердой беспристрастностью, может без угрызений совести уйти в другую организацию, где предлагают более высокую оплату. Каждый отдельный мотив тре- бует отдельного объяснения, но не требует объяснения тот факт, что они взаимодействуют друг с другом. Неправдоподобно лишь действие единственной мотивации, существование нормы настолько сильной, что она контролирует все поступки человека.

\section{Список литературы / References}

1. Cooter R. The Best Right Laws: Value Foundations of the Economic Analysis of Law, Notre Dame Law Review, 1989, vol. 64, pp. 817-837.

2. Dau-Schmidt K. Economics and Sociology: The Prospects for an Interdisciplinary Discourse on Law, Wisconsin Law Review, 1997, pp. 389-420.

3. Posner E. Law and Social Norms, Cambridge, Mass.: Harvard University Press, 2002.

4. Ellickson R. Order Without Law: How Neighbors Settle Disputes, Cambridge, Mass.: Harvard University Press, 1994.

5. Green D., Shapiro I. Pathologies of Rational Choice Theory: A Critique of Applications in Political Science, New Haven, Conn.: Yale University Press, 1994.

6. Brown S., Brown R., Penner L. Moving Beyond Self-Interest: Perspectives from Evolutionary Biology, Neuroscience, and the Social Sciences, Oxford: Oxford University Press, 2012.

7. Mansbridgc J. Beyond Self-interest, Chicago. IL: University of Chicago Press, 1990.

8. Rubin E. Soul. Self and Society: The New Morality and the Modern State. New York: Oxford University Press, 2015.

9. Weber M. The Protestant Ethic and the "Spirit" of Capitalism, Los Angeles: Roxbury, 2002 [1904-05].

10. Tawney R. H. Religion and the Rise of Capitalism, New York: Mentor Books, 1954.

11. Ferejohn J. Rationality and interpretation: parliamentary elections in early Stuart England, The Economic Approach to Politics: A Critical Reassessment of the Theory of Rational Action, ed. Monroe K., New York: Harper Collins, 1991.

12. Dante A. The Divine Comedy, New York: New American Library, 2003.

13. Frankfurt H. The Importance of What We Care About: Philosophical Essays, Cambridge, Eng.: Cambridge University Press, 1988.

14. Dostoyevsky F. Crime and Punishment, New York: Dell Publishing, 1959 [1866].

15. Hardin R. Magic on the frontier: the norm of efficiency, University of Pennsylvania Law Review, 1996, vol. 144, pp. 1987-2020.

16. Kuran T. Private Truths, Public Lies: The Social Consequences of Preference Falsification, Cambridge, Mass.: Harvard University Press, 1997.

17. Coleman J. Foundations of Social Theory, Cambridge, Mass.: Belknap Press, 1990.

18. Veyne P. The Roman Empire, A History of Private Life, ed. Veyne P., Cambridge, Mass: Belknap Press, 1987.

19. The World of Athens: An Introduction to Classical Athenian Culture, Joint Association of Classical Teachers, Cambridge, Eng.: Cambridge University Press, 1984.

20. Ober J. Mass and Elite in Democratic Athens: Rhetoric, Ideology and the Power of the People, Princeton, N. J.: Princeton University Press, 1989.

21. Bringmann K. A History of the Roman Republic, Cambridge, Eng.: Polity Press, 2007.

22. Gruen E. Rome and the Greek world, in Flower H. The Cambridge Companion to the Roman Republic, New York: Cambridge University Press, 2004.

23. Wells C. The Roman Empire, 2 ${ }^{\text {nd }}$, Cambridge, Mass.: Harvard University Press, 1992.

24. Heather P. The Fall of the Roman Empire: A New History of Rome and the Barbarians, Oxford, Eng.: Oxford University Press, 2006.

25. Blair P. Roman Britain and Early England, 55 B.C. - A.D. 871, New York: W.W. Norton, 1963.

26. Aristotle The Athenian Constitution, The Works of Aristotle, Chicago: Encyclopedia Britannica, 1952.

27. Fox R. L. Pagans and Christians, New York: Harper \& Row, 1986.

28. Brown P. The World of Late Antiquity, New York: W.W. Norton, 1989.

29. Wickham C. The Inheritance of Rome: Illuminating the Dark Ages 400-1000, New York: Viking, 2009.

30. Salway P. Roman Britain, Oxford: Oxford University Press, 1981.

31. Geary P. Before France and Germany: The Creation and Transformation of the Merovingian World, Oxford, Eng.: Oxford University Press, 1988.

32. Goldsworthy A. How Rome Fell: Death of a Superpower, New Haven, Conn.: Yale University Press, 2009. 
33. Adams H. Mont Saint Michel and Chartres, New York: Penguin, 1986 [1904].

34. Simson O. The Gothic Cathedral: Origins of Gothic Architecture and the Medieval Concept of Order, $3^{\text {rd }}$ ed., Princeton, N. J.: Princeton University Press, 1988.

35. Cantor N. The Civilization of the Middle Ages, New York: Harper Perennial, 1994.

36. Markale J. Courtly Love: The Path of Sexual Initiation, Rochester, Vt.: Inner Traditions, 1987.

37. Turnbull C. The Forest People, New York: Simon \& Schuster, Inc., 1968.

38. Turnbull C. The Mountain People, New York: Simon \& Schuster, Inc., 1972.

39. Heine B. The mountain people: some notes on the Ik of Northern Uganda, Africa, 1985, vol. 55, No. 1, pp. 3-16.

40. Musasizi S. Meet the Ik: Karamoja's original tribe on the verge of extinction, 2013, available at: http://observer.ug/index. php?option=com_content\&view=article\&id=27912:meet-the-ik-karamojas-original-tribe-on-verge-of-extinction\&catid=73:high lights\&Itemid $=70$.

41. Berger P. L., Luckmann T. The social construction of reality: A treatise in the sociology of knowledge, NY: First Anchor, 1966.

42. Goodman N. Ways of Worldmaking, Indianapolis: Hackett Publishing, 1978.

43. Habermas J. The Theory of Communicative Action, Boston: Beacon Press, 1987.

44. Winch P. The Idea of a Social Science and its Relation to Philosophy, London: Routledge \& Kegan Paul, 1958.

45. Finley M. I. The World of Odysseus, New York: Viking Press, 1965.

46. MacIntyre A. After Virtue, $2^{\text {nd }}$ ed., Notre Dame, Ind.: University of Notre Dame Press, 1984.

47. Lewis D. God's Crucible: Islam and the Making of the Europe, 570-1215, New York: W.W. Norton, 2008.

48. Ward-Perkins B. The Fall of Rome and the End of Civilization, Oxford, Eng.: Oxford University Press, 2005.

49. Le Goff J. Merchant's time and church's time in the Middle Ages, Time, Work and Culture in the Middle Ages, ed. LeGoff

J., Chicago: University of Chicago Press, 1980.

50. Le Goff J. Licit and illicit trades in the Medieval West, 1980.

51. Schama S. The Embarrassment of Riches: An Interpretation of Dutch Culture in the Golden Age, New York: Vintage Books, 1997.

52. Troeltsch E. Protestantism and Progress: A Historical Study of the Relation of Protestantism to the Modern World, New

York: G.P. Putnam's Sons, 1912.

53. Godfrey W. John Calvin: Pilgrim and Pastor, Wheaton, Ill.: Crossways Books, 2009.

54. Gordon B. Calvin, New Haven, Conn.: Yale University Press, 2009.

55. Lopez R. The Birth of Europe, New York: M. Evans \& Co, 1966.

56. Pirenne H. Mohammed and Charlemagne, London: George Allen \& Unwin, 1954.

57. Bartlett R. The Making of Europe: Conquest, Colonization and Cultural Change 950-1350, Princeton, N.J.: Princeton University Press, 1993.

58. Gies J., Gies F. Life in a Medieval City, New York: Harper \& Row, 1969.

59. Mundy J., Riesenberg P. The Medieval Town, Princeton, N.J.: D. Van Nostrand Co., 1958.

60. Pirenne H. Medieval Cities: Their Origins and the Revival of Trade, Princeton, N. J.: Princeton University Press, 1952.

61. Hay D. Europe in the fourteenth and fifteenth centuries, New York: Holt, Rinehart and Winston, 1966.

62. Elias N. The Civilizing Process, Oxford, Eng.: Blackwell, 1994 [1939].

63. Ogg D. Europe in the Seventeenth Century, New York: Collier Books, 1960.

64. Hay D. Europe in the Fourteenth and Fifteenth Centuries, London: Longman, 1989.

65. Renouard Y. The Avignon Papacy 1305-1403, London: Faber and Faber, 1970.

66. MacCulloch D. The Reformation: A History, New York: Penguin Books, 2003.

67. Skinner Q. The Foundations of Modern Political Thought, Cambridge, Eng.: Cambridge University Press, 1978.

68. Gay P. The Enlightenment: The Rise of Modern Paganism, New York: W.W. Norton \& Co., 1977.

69. Bruce S. God is Dead: Secularization in the West, Malden, Mass.: Blackwell Publishing, 2002.

70. Chadwick O. The Secularization of the European Mind in the 19th Century, Cambridge, Eng.: Cambridge University Press, 1975.

71. Herman A. How the Scots Invented the Modern World, New York: Three Rivers Press, 2001.

72. Himmelfarb G. The Roads to Modernity: The British, French, and American Enlightenments, New York: Vintage, 2005.

73. Smith A. The Theory of Moral Sentiments, Oxford, Eng.: Oxford University Press, 1976 [1959].

74. Smith A. The Wealth of Nations: Books I-III, London: Penguin Books, 1986 [1776].

75. Mandeville B. The Fable of the Bees, or Private Vices, Publick Benefits, Indianapolis: Liberty Fund, Inc., 1988 [1724].

76. Rubin E. Beyond Camelot: Rethinking Politics and Law for the Modern State, Princeton, N. J.: Princeton University Press, 2005.

77. Bernstein L. Opting out of the legal system: extra-legal contractual relations in the diamond industry, Journal of Legal Studies, 1992, vol. 21, pp. 115-157.

78. Bernstein L. Merchant law in a merchant court: rethinking the code's search for immanent business norms, University of Pennsylvania Law Review, 1996, vol. 144, pp. 1765-1821. 
79. Cooter R. Decentralized Law for a Complex Economy: The Structural Approach to Adjudicating the New Law Merchant, University of Pennsylvania Law Review, 1996, vol. 144, pp. 1643-1696.

80. Rock E., Wachter M. The enforceability of norms and the employment relationship, University of Pennsylvania Law Review, 1996, vol. 144, pp. 1913-1952.

81. Ferejohn J., Fiorina M. The paradox of not voting: A Decision Theory analysis, American Political Science Review, 1974, No. 68 , pp. 525-536.

82. Kostritsky J. The law and economics of norms, Texas International Law Journal, 2013, No. 48, pp. 465-505.

83. Levmore S. Norms as supplements, Virginia Law Review, 2000, No. 86, p. 1989.

84. Eisenberg M. Corporate law and social norms, Columbia Law Review, 1999, No. 99, p. 1253.

85. MacCaulay S. Non-Contractual Relations in Business: A Preliminary Study, American Sociological Review, 1963, No. 28, pp. 55-72.

86. Cooter R. Three effects of social norms on law: expression, deterrence, and internalization, Oregon Law Review, 2000, No. 79, pp. 1-22.

87. Husserl E. Ideas: General Introduction to Pure Phenomenology, New York: Collier Books, 1962.

88. Husserl E. The Crisis of the European Sciences and Transcendental Phenomenology: An Introduction to Phenomenological Philosophy, Evanston, Ill.: Northwestern University Press, 1970.

89. Cho S. Beyond Rationality: A Sociological Construction of the World Trade Organization, Virginia Journal of International Law, 2012, No. 52, pp. 321-354.

90. Edelman L. Rivers of Law and Contested Terrain: A Law and Society Approach to Economic Rationality, Law and Society Review, 2004, No. 28, pp. 181-197.

91. Coontz S. Marriage, a History: How Love Conquered Marriage, New York: Penguin Books, 2005.

92. Duby G. Medieval Marriage: Two Models from Twelfth Century France, Baltimore: Johns Hopkins University Press, 1978.

93. Gies F., Gies J. Marriage and the Family in the Middle Ages, New York: Harper Perennial, 1987.

94. Thomas K. The Ends of Life: Paths to Fulfillment in Early Modern England, Oxford, Eng.: Oxford University Press, 2009.

95. Brundage J. Law, Sex, and Christian Society in Medieval Europe, Chicago: University of Chicago Press, 1987.

96. Hetherington E. For Better or For Worse: Divorce Reconsidered, New York: W.W. Norton, 2003.

97. Rubin E. The dominance of norm, Law and Economics: Philosophical Issues and Fundamental Questions, ed. Hatzis A. N., Mercuro N. Routledge, 2015, pp. 43-68.

(C) Рубин Э., 2017. Впервые опубликовано на русском языке в журнале «Актуальные проблемы экономики и права» (http://apel.ieml.ru), 20.06.2017

(C) Rubin E. L., 2017

\section{Информация об авторе}

Рубин Эдвард, профессор права и политологии, Школа права, Университет Вандербильта

Адрес: 131 21st Avenue South, Nashville, TN, USA, 37203, tel.: +1 (615) 322-5620

E-mail: ed.rubin@vanderbilt.edu

\section{Information about the author}

Edward L. Rubin, Professor of Law and Political Science, Vanderbilt University Law School, Nashville, TN, USA Address: 131 21st Avenue South, Nashville, TN, USA, 37203, tel.: (615) 322-5620

E-mail: ed.rubin@vanderbilt.edu 